\title{
Modelling changes in the energy efficiency of buildings using neural networks on the example of Zielona Góra
}

\author{
Andrzej Łączak¹, Maria Mrówczyńska² , Anna Bazan - Krzywoszańska² and Marta Skiba2,a \\ ${ }^{1}$ State School of Higher Professional Education in Sulechów, Institute of Law and Tourism, 66-100 Sulechów, Armii Krajowej 51, Poland \\ ${ }^{2}$ University of Zielona Góra, Faculty of Civil Engineering, Architecture and Environmental Engineering, 65-417 Zielona Góra, Licealna 9, \\ Poland
}

\begin{abstract}
The objective of this article is to find a way to pursue optimum spatial policy on the local level to meet the assumptions of the energy policy of the European Union. One of the possible ways of developing energy efficient civil engineering is varied town policy and programmes supporting energy efficient buildings. And the second is the use of renewable energy sources as a factor improving the energy safety of built areas and reducing the emission of greenhouse gases. And the third is the optimization of expenditure on these goals in towns. Although our current research and estimations based on it are limited to a medium-sized town in the west of Poland, the observations included in this article may be important for other regions that are interested in reducing energy consumption in buildings, residential areas and towns. Taking into account the geographical context, it is especially important for these regions of Europe that are obtaining financial aid from the European Union in the perspective for the years 2014-2020.
\end{abstract}

\section{Introduction}

The participation of cities in the global consumption of energy is constantly increasing and there is no indication that this trend will change. Increasing population, increasing demand for construction services and raising the level of comfort, with the increase in time spent in buildings, provides the be upward trend in energy demand. Reducing the amount of energy needed to ensure and maintain thermal comfort is a common goal that all developed societies, driven both by rising energy costs and environmental concerns, such as reducing carbon dioxide emissions. The increase in the level of heat and power consumption may not, however, be reduced below the thresholds set out in the strategies, and based only on insulation or ventilation control. There is also a need for energy from natural and renewable sources [1].

Reducing consumption of thermal, electrical and gas energy and an increase in the efficiency of devices in buildings is the main objective of the energy policy at regional, national and international levels today. This goal is also reflected in the local policy, setting out the scope for investments. The popularity of smart ways to design and construct more energy-efficient buildings, as well as increase their comfort has been growing in construction and architecture [2,3]. Numerous case studies are known in the literature, that describe and analyze individual projects to increase energy efficiency, depending on the environmental conditions, the characteristics of the building and supporting technology used to reduce energy consumption, energy costs and $\mathrm{CO}$ 2 emissions in buildings, also through the active technologies, such as photovoltaic panels $[4,5]$, solar panels [6], wind turbines [3.7] or heat pump systems [8]. Important economic benefits were described due to the application of the simultaneous production of electricity, heating and cooling in cogeneration [9].

The economic justification of the future of energyefficient construction without the possibility of obtaining funds from the European Union (also in the new perspective 2014-2020) is very difficult to achieve [10]. There is a need for public intervention in the forms of colour energy certificates, subsidies, tax exemptions, promotions and good practices to encourage a more efficient use of energy in households. Communal and city municipal authorities are the main bodies responsible for monitoring processes of reducing energy demand.

One of the possible ways of development of energyefficient construction is the diversity of urban policy and the launch of programmes to promote energy-efficient construction. The second one is the promotion of good practices and examples, for instance by the pressure on low-energy construction of municipal and local authorities buildings. Third, is the use of renewable energy sources as means to improve safety and energy balance. And the fourth one is the optimization of spending the financial resources intended for these purposes in a city [10].

\footnotetext{
a Corresponding author: M.Skiba@aiu.uz.zgora.pl
} 
Presented modelling, you made on the basis of the GIS data for the city ${ }^{1}$ of medium size in the western part of Poland. The observations and conclusions presented in this article may be relevant for regions that are interested in reducing the energy consumption of buildings, housing estates and towns. Taking the geographical context into account, it is especially important for those regions which benefit from financial support of the European Union over the 2014-2020 perspective. The process of reaching the values of the energy balance, provided for by the European Commission, will not be quick if these values are referred to only by the insulation parameters of particular elements of wall barriers, increase in devices ' efficiency and energy characteristics of an apartment or a building without specifying the requirements of improving energy efficiency in the scale of the housing estate, the district and the city.

Making actions aimed at improving the efficiency and reducing the demand for heat and electricity dependant only from the economic benefits, the influences on the economic situation of families, which is related to the notion of energy poverty. Energy poverty depends primarily on family income and energy prices (Household Budget Survey ${ }^{2}$, GUS 2014). Antienergy poverty strategy requires actions to be taken in order to reduce energy prices and its availability (rationing) and taking actions aiming to intensive use of the infrastructure, which is contributed by the concentration of people [11]. These objectives can be achieved, inter alia, by conducting a responsible urban policy requiring control-direct action and economic incentive.

\section{Energy efficiency requirements}

Poland, like the countries that joined the European Union in the 21 st century, faces the need to adapt the development policy to the requirements of the Union in terms of reducing the production of greenhouse gases, mainly by reducing the operational demand for heat, electricity, gaseous fuels [12-14]. In accordance with article 9 par. 3 item (b) of the directive 2010/31/EU, a National Energy Efficiency Action Plan for Poland 2014 [15] was prepared, which includes, inter alia, the intermediate targets to improve the energy performance of new buildings for the year 2015, with a view to the preparation of implementing the assumption that until 31 December 2020 all newly constructed buildings are near-zero energy buildings, and after 31 December 2018 new buildings occupied and public buildings are near-zero energy consumption buildings.

On the basis of article 4 of the 2012/27/EU directive Supporting Investments for Buildings Modernisation [16] document was prepared in the Ministry of Infrastructure and the Development. It is an annex to the National Energy Efficiency Action Plan for Poland 2014, which was prepared due to the obligation

License no DR-G.6642.1059.2016.AW_0862_Pof 14.03.20E16 of reporting to the European Commission on the implementation of the directive 2012/27/EU, as well as on the basis of the obligation imposed on the Minister of Economy in article 6 par. 1 of the Energy Efficiency Act of 15 April 2011 [17,18]. This document contains, inter alia, a description of the planned energy efficiency improvements specifying the actions taken to improve energy efficiency in various sectors of the economy, necessary to implement the national target for economical energy management for 2016, as well as a review of the final energy savings to be reached in 2020 .

It seems, however, that if communes and cities do not cooperate, and the effects of the public consultation do not become part of the arrangements of local zoning plans [19], a mechanism to support small and microinstallations will not be an incentive for the development of renewable energy sources (RES). One of the reasons is that the regulations concerning the energy efficiency of buildings are constructed in such a way that meeting the requirements in force from 1 January 2021 and thus achievement of the required values of Primary Energy Factor using conventional solutions (including the use of better thermal insulation wall barriers and recovery and improving the efficiency of central heating and hot utility water systems) is associated with significant investments limitations of a building features or functionality, to which we are accustomed [20]. This is a deliberate measure, which is meant to encourage investors to use alternative sources of energy, including renewable energy, heat pumps and cogeneration heat and power in buildings. The effectiveness of this measure will depend on the cost of the applied solutions.

\subsection{Support for energy efficiency}

Supporting energy efficiency in public buildings and residential sector has become one of the tasks carried out under the EU funds for 2014-2020 inPoland. These tasks are implemented in the Infrastructure and Environment Operational Programme, and 16 regional programmes. In Zielona Góra there is a possibility to use two programs of the Regional Operational Programme - Lubuskie 2020 and National Infrastructure and Environment Operational Programme. Three following actions supporting energy efficiency in buildings are planned: -supporting energy efficiency in public buildings, -supporting energy efficiency in the residential sector, -creating a nationwide system of advisory support on energy efficiency and RES for the public, housing and business sectors .

The implementation of these activities is intended to contribute to the deep comprehensive energy retrofit, which may include:

- thermal insulation of the building

- exchange of equipment objects on energy-efficient equipment, among others, replacement of windows, exterior doors, the modernization of the internal heating and preparing hot utility water facilities, and common lighting parts to energy-efficient.

\footnotetext{
${ }^{2}$ http/stat.gov.pl
} 
- reconstruction of heating systems and mechanical ventilation systems,

- installation of renewable energy sources in the energyefficient modernized buildings,

- introduction of energy management systems.

The scope of the project must lead to a reduction in final energy consumption by at least $25 \%$. Total funding for this purpose within the Operational Programme for Infrastructure and Environment is 421 278811 EUR [21].

The second program available in Zielona Góra is the Lubuskie Regional Operational Programme - Lubuskie 2020, priority third-low carbon Economy (Table 1). 108 005260 euro is provided for the implementation of the entire priority. Under this priority, investments in renewable energy, energy efficiency, low-emission limit in cities and cogeneration are provided.

Table 1. The value of the funding in priority third Regional Operational Programme-Lubuskie2020 for 2014-2020 [EUR].

Source: Own studies based on the Regional Operational Programme-Lubuskie 2020.

\begin{tabular}{|c|c|}
\hline The title of the action & $\begin{array}{c}\text { The value of the grant in } \\
\text { EUR }\end{array}$ \\
\hline Renewable energy sources & 19601052 \\
\hline Energy efficiency & 39202104 \\
\hline $\begin{array}{c}\text { Low emission reduction in } \\
\text { cities }\end{array}$ & 36134736 \\
\hline Cogeneration & 13067368 \\
\hline
\end{tabular}

The maximum level of granting in all programs is $85 \%$ of the eligible expenditure of the project.

\subsubsection{Public buildings}

In the current financial perspective of the EU public buildings have gained in importance. The legal basis under a new perspective, was being prepared from 2010. Article 9 par. 2 of the directive 2010/31/EU specifies that Member States "shall furthermore, following the leading example of the public sector, develop policies and take measures such as the setting of targets in order to stimulate the transformation of buildings that are refurbished into nearly zero-energy buildings, and inform the Commission thereof in their national plans" [13].

Article. 4 of the directive of the European Parliament and of the Council of 2012/27/EU of 25 October 2012 on energy efficiency, amending Directives 2009/125/EC and 2010/30/EU and repealing Directives 2004/8/EC and 2006/32/EC (Official Journal of the EU L 315 of 14.11.2012, p. 1, as amended), hereinafter referred to as "the directive 2012/27/EU"imposes the obligation to establish a long-term strategy for mobilising investment in the renovation of residential and commercial buildings, both public and private (Table 2). This strategy includes:

- an overview of the national building stock based, as appropriate, on statistical sampling;

- identification of cost-effective approaches to renovations relevant to the building type and climatic zone;

- policies and measures to stimulate cost-effective deep renovation of buildings;
- including staged deep renovations;

- a forward-looking perspective to guide investment decisions of individuals, the construction industry and financial institutions;

- an evidence-based estimate of expected energy savings and wider benefits"[14].

In accordance with $\S 3$, point 6 . Regulation of the Minister of Infrastructure on the technical specifications which should correspond to the buildings and their position of 17 July 2015. (Journal of Laws of 2015 item 1422) [22], a public building - shall mean "the building designed for the needs of public administration, justice, culture, worship, education, higher education, science, upbringing, health care, social care, banking, trade, catering, services, including postal services or telecommunications, tourism, sport, serving passengers in transport by rail, road, air, sea or inland waterway, and another building designed to perform similar functions; public building shall also mean an office or amenity building".

Table 2. Intermediate objectives to improve the energy performance of new buildings. Source: Own studies based on the Regulation of the Minister of Infrastructure on the technical specifications which should correspond to the buildings and their position of 12 April 2002. (Journal of Laws No. 75, item. 690).

\begin{tabular}{|c|c|}
\hline \multicolumn{2}{|c|}{ near-zero energy cons umption buildings } \\
\hline after 31 December 2018 & after 31 December 2020 \\
\hline $\begin{array}{l}\text { new buildings occupied and } \\
\text { owned by municipalities }\end{array}$ & all new buildings \\
\hline
\end{tabular}

\subsection{Funding and support}

Thermal renovation of buildings is generally highly profitable, but requires incurring significant initial costs, therefore, many building owners may not accomplish the thermal renovation without a financial support of the state. The State support system for buildings owners has been specified in The Act of supporting thermomodernisation and renovation of 21 November 2008 (Journal of Laws 2008, No. 223 item 1459) [23]; The system aims to facilitate funding thermal renovation in order to reduce energy consumption and costs of heating the buildings and preparing hot utility water. The act introduces new granting rules for thermal renovation purposes, and the helping system is introduced to encourage a certain group of renovations.

In the field of energy efficiency and cogeneration on the territory of the town of Zielona Gora a total of 10 projects were completed. The projects were implemented within the two programs - Infrastructure and Environment Operational Programme, and Lubuskie Regional Operational Programme (Table 3). In the field of renewable energy only one project was completed (Table 4).

\section{Method and object of research}

The research focused on the buildings owned by the City Hall (municipalities) within the city of Zielona Góra, which is located in the western part of Poland. In order to determine the energy potential, meant as the ability to make effective use of local resources, the city was 
Table 3. Projects completed in the field of energy efficiency in Zielona Gora within the energy efficiency in the financial perspective 2007-2013 in EUR (1EUR=4,36 PLN for day 22.07.2016 r. [29]). Source: Own studies based on the KSI-SIMIK (2007-2013)

(National Information Technology System- Information Technology System for Monitoring and Financial Control of the Structural Funds and the Cohesion Fund).

\begin{tabular}{|c|c|c|c|c|c|c|}
\hline Title of the project & $\begin{array}{c}\text { The Ope rational } \\
\text { Programme }\end{array}$ & $\begin{array}{l}\text { Total } \\
\text { value }\end{array}$ & $\begin{array}{c}\text { Eligible } \\
\text { Expen diture }\end{array}$ & Funding & $\begin{array}{c}\text { EU } \\
\text { funding }\end{array}$ & Bene ficiary's name \\
\hline $\begin{array}{l}\text { Modernization and reconstruction of } \\
\text { heat supply system in Zielona Góra }\end{array}$ & $\begin{array}{l}\text { The Infrastructure } \\
\text { and Environment } \\
\text { Operational } \\
\text { Programme }\end{array}$ & $\begin{array}{c}12581 \\
135\end{array}$ & 9776965 & 8310420 & $\begin{array}{c}8310 \\
420\end{array}$ & $\begin{array}{l}\text { Elektrociepłownia "Zielona } \\
\text { Góra" S.A. }\end{array}$ \\
\hline $\begin{array}{l}\text { Low carbon economy in the } \\
\text { functional area of the provincial city } \\
\text { of Zielona Gora }\end{array}$ & $\begin{array}{l}\text { The Infrastructure } \\
\text { and Environment } \\
\text { Operational } \\
\text { Programme }\end{array}$ & 18804 & 18804 & 15372 & 15372 & Zielona Góra city \\
\hline $\begin{array}{l}\text { Thermal renovation of the main } \\
\text { building of the C.Norwid Provincial } \\
\text { and Municipal Public Library in } \\
\text { Zielona Góra }\end{array}$ & $\begin{array}{l}\text { The Lubuskie } \\
\text { Regional } \\
\text { Operational } \\
\text { Programme }\end{array}$ & $\begin{array}{c}2149 \\
567\end{array}$ & 2018633 & 1378171 & $\begin{array}{c}1378 \\
171\end{array}$ & $\begin{array}{l}\text { C. Norwid Provincial and } \\
\text { Municipal Public Library } \\
\text { in Zielona Góra }\end{array}$ \\
\hline $\begin{array}{l}\text { Thermal renovation of the Police } \\
\text { Headquarters building in Zielona } \\
\text { Góra }\end{array}$ & $\begin{array}{l}\text { The Lubuskie } \\
\text { Regional } \\
\text { Operational } \\
\text { Programme }\end{array}$ & $\begin{array}{l}414 \\
571\end{array}$ & 414571 & 352385 & 352385 & $\begin{array}{l}\text { Provincial Police } \\
\text { Headquarters in Gorzow } \\
\text { Wielkopolski }\end{array}$ \\
\hline $\begin{array}{l}\text { Thermal renovation of the Roman } \\
\text { Catholic Parish of the Holy Spirit in } \\
\text { Zielona Góra buildings including } \\
\text { the exchange of a heat system for an } \\
\text { eco-friendly hybrid heating system } \\
\text { based on RES }\end{array}$ & $\begin{array}{l}\text { The Lubuskie } \\
\text { Regional } \\
\text { Operational } \\
\text { Programme }\end{array}$ & $\begin{array}{l}773 \\
228\end{array}$ & 773228 & 657243 & 657243 & $\begin{array}{l}\text { Roman Catholic Parish of } \\
\text { the Holy Spirit in Zielona } \\
\text { Góra }\end{array}$ \\
\hline $\begin{array}{l}\text { "Thermal renovation of a Tennis } \\
\text { Hall and the Facility Building " }\end{array}$ & $\begin{array}{l}\text { The Lubuskie } \\
\text { Regional } \\
\text { Operational } \\
\text { Programme }\end{array}$ & $\begin{array}{l}818 \\
079\end{array}$ & 544456 & 381119 & 381119 & $\begin{array}{l}\text { Lubuskie Voivodeship } \\
\text { represented by the } \\
\text { Provincial Sports and } \\
\text { Recreation Centre in } \\
\text { Drzonkow }\end{array}$ \\
\hline $\begin{array}{l}\text { Thermal renovation of educational } \\
\text { buildings in Zielona Góra }\end{array}$ & $\begin{array}{l}\text { The Lubuskie } \\
\text { Regional } \\
\text { Operational } \\
\text { Programme }\end{array}$ & $\begin{array}{l}964 \\
642\end{array}$ & 964642 & 819945 & 819945 & Zielona Góra city \\
\hline $\begin{array}{l}\text { Thermal renovation of the } \\
\text { Provincial Labour Office building in } \\
\text { Zielona Góra }\end{array}$ & $\begin{array}{l}\text { The Lubuskie } \\
\text { Regional } \\
\text { Operational } \\
\text { Programme }\end{array}$ & $\begin{array}{l}173 \\
689\end{array}$ & 126080 & 107168 & 107168 & $\begin{array}{l}\text { Lubuskie Voivodeship } \\
\text { represented by the } \\
\text { Provincial Labour Office in } \\
\text { Zielona Góra }\end{array}$ \\
\hline $\begin{array}{l}\text { Reconstruction of the boiler-room in } \\
\text { State Music School building in ul. } \\
\text { Chrobrego } 26 \text {, Zielona Góra, from } \\
\text { coal to gas supplied. }\end{array}$ & $\begin{array}{l}\text { The Lubuskie } \\
\text { Regional } \\
\text { Operational } \\
\text { Programme }\end{array}$ & 33082 & 25509 & 21683 & 21683 & $\begin{array}{l}\text { The State Music School of } \\
1 \text { st and } 2 \text { nd level }\end{array}$ \\
\hline $\begin{array}{l}\text { Thermal renovation of the Public } \\
\text { Health Care Centre of the Ministry } \\
\text { of the Interior buildings in ul. } \\
\text { Wazów 42, Zielona Góra }\end{array}$ & $\begin{array}{l}\text { The Lubuskie } \\
\text { Regional } \\
\text { Operational } \\
\text { Programme }\end{array}$ & $\begin{array}{l}778 \\
208\end{array}$ & 522193 & 443864 & 443864 & $\begin{array}{l}\text { Independent Public Health } \\
\text { Care Centre of the Ministry } \\
\text { of the Interior in Zielona } \\
\text { Góra }\end{array}$ \\
\hline Total & & $\begin{array}{c}18705 \\
005\end{array}$ & 15185081 & $\begin{array}{c}12487 \\
370\end{array}$ & $\begin{array}{c}12487 \\
370\end{array}$ & \\
\hline
\end{tabular}




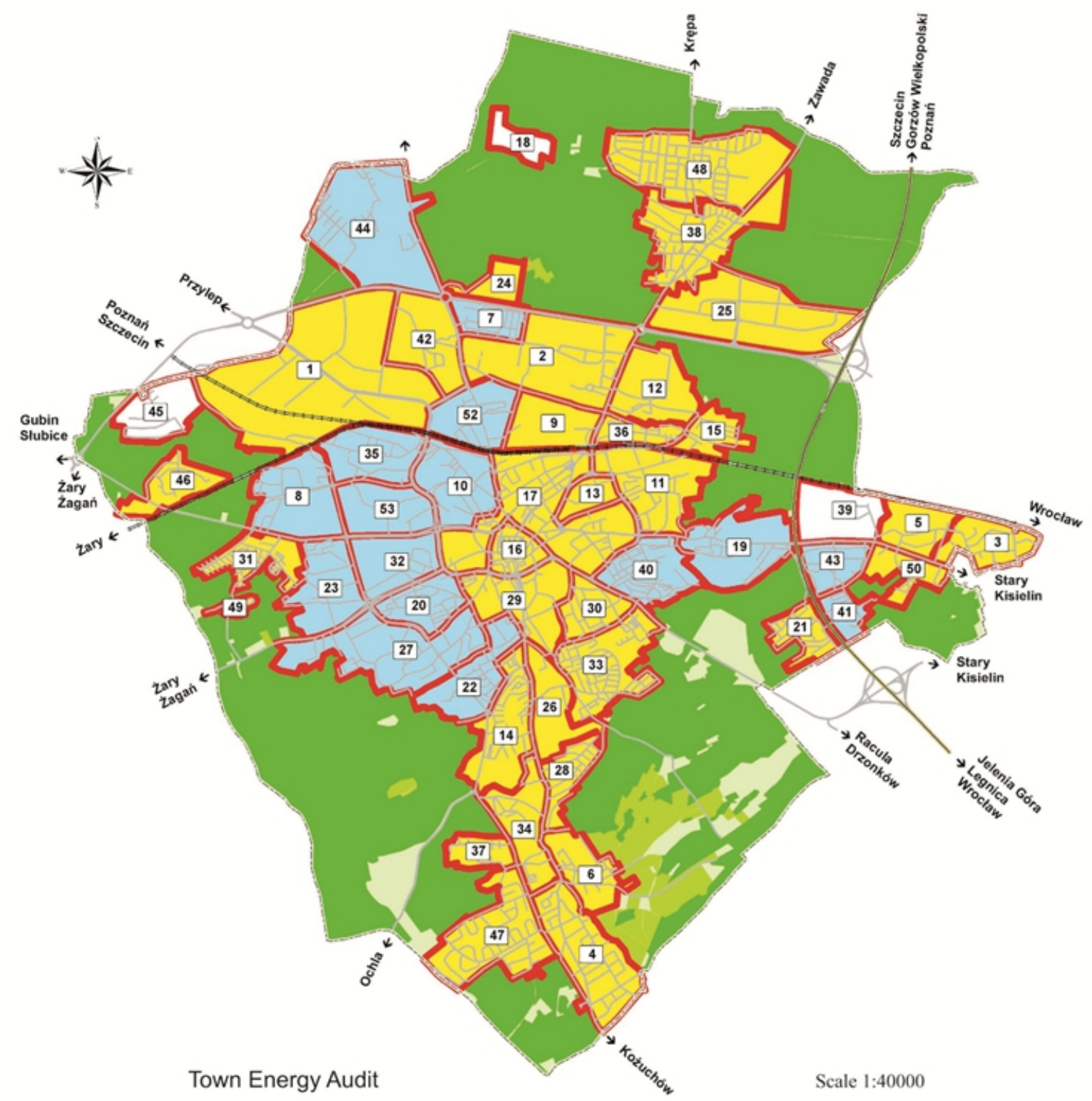

Map with a division into zones according to the prevalent time of buildings

\section{Legend}

Boundary of the town of Zielona Góra

Polish State Railway lines

Streets

Zone

Forest

Functional gardens

Boundary town areas

Town areas where most buildings were construction of prefabrication elements

Town areas where most buildings were construction of traditional elements

Figure 1. The division of research area. Source: [20]. 
Table 4. RES projects realised in Zielona Góra under the EU funds in the 2007-2013 in EUR. Source: Own studies based on the KSISIMIK (2007-2013) (National Information Technology System- Information Technology System for Monitoring and Financial Control of the Structural Funds and the Cohesion Fund).

\begin{tabular}{|l|l|c|c|c|c|l|}
\hline \multicolumn{1}{|c|}{ Title of the project } & \multicolumn{1}{|c|}{$\begin{array}{c}\text { The Operational } \\
\text { Programme }\end{array}$} & $\begin{array}{c}\text { Total } \\
\text { value }\end{array}$ & $\begin{array}{c}\text { Eligible } \\
\text { Expenditu } \\
\text { re }\end{array}$ & Funding & $\begin{array}{c}\text { EU } \\
\text { Funding }\end{array}$ & Beneficiary's name \\
\hline $\begin{array}{l}\text { The modernization of the } \\
\text { heating systemwith the use of } \\
\text { solar panels in the "L" building } \\
\text { of the Provincial Hospital SP } \\
\text { ZOZ in Zielona Góra }\end{array}$ & $\begin{array}{l}\text { The Lubuskie } \\
\text { Regional Operational } \\
\text { Programme }\end{array}$ & 139115 & 136406 & 113871 & 113871 & $\begin{array}{l}\text { Karol Marcinkowski } \\
\text { Provincial Hospital } \\
\text { Independent Public Health } \\
\text { Care Centre in Zielona Góra }\end{array}$ \\
\hline
\end{tabular}

divided into 50 districts, differentiated in terms of functions, construction technologies, construction date, and buildings condition (fig. 1).

\subsection{Research area - Zielona Góra}

The study examined two areas with the highest and lowest index of development with public buildings. Public buildings are 55.6\% (quarter 17) and 20.2\% (quarter 32) of buildings in designated areas for which factors affecting energy consumption and estimated energy potential were examined. These factors included: technology and construction year(most related to the used building materials), dominant functions and the location of the district, associated with a source for obtaining heat and energy (solid fuels, gas, cogeneration). In this way, the data was obtained, which was used to determine the potential savings arising from achieving the standard $95 \mathrm{kWh} / \mathrm{m}^{2} /$ year, and the standard $70 \mathrm{kWh} / \mathrm{m}^{2} /$ year in public buildings.

\subsubsection{Sigmoid neutral networks}

Neural networks are modelling technique, which allows the representation of extremely complex functions. As a convenient non-linear tool they are used in solving problems in such unrelated areas as: finance, medicine, engineering, geology, physics, and many others. Neural networks work well wherever a linear approximation is not applicable to describe the phenomena, because models created with the use of neural networks easily reflect non-linear relations. Sigmoid artificial neural network represent a class of mathematical algorithms which have a strong theoretical basics and usability in practice. They are systems in the form of interconnected neurons, where computing power allows to carry out mapping of the input space to the output [24]. This mapping is implemented by a process of training the network. Network training is carried out by forcing it to such a reaction, which meets the relevant requirements with respect to the input signal. Scheme of mapping the input vector

$$
\mathbf{x} \in R^{N}
$$

in the output vector

$$
\mathbf{y}(\mathbf{x}) \in R^{M}
$$

is shown in Figure 2 [25]. Symbols used in the formulas (1) and (2), and in Figure 2 are defined as follows: $\mathbf{x}$ input vector; y - output vector; $R N, R M-N$ and $M$ dimensional set of real numbers; $v$-the hidden layer weights, $w$ - the output layer weights.
In the presented work sigmoid multilayer neural network trained by back propagation error technique were used to model the potential savings resulting from the need to reduce energy consumption in existing public buildings to $95 \mathrm{kWh} / \mathrm{m}^{2} /$ year until 2017, and to $70 \mathrm{kWh} / \mathrm{m}^{2} /$ year until 2021 [22].

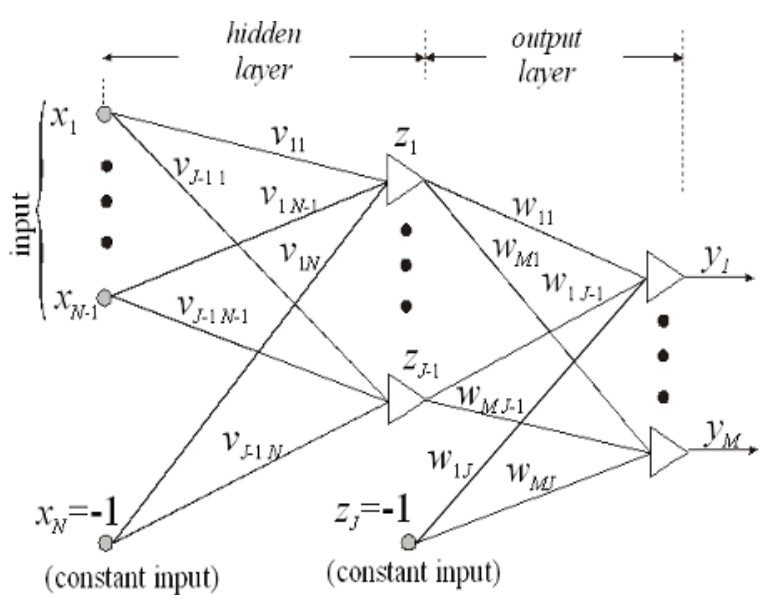

Figure 2. The mapping of the input vector $\mathbf{X}$ in the output vector $\mathbf{y}$.

Training and testing the network was conducted on two areas of the city of Zielona Góra, in which the largest (quarterly 17) and the smallest (quarter 32) number of public buildings was located (table 5). Neural network used in the work to the approximation of potential savings within the analysed quarters, was a two-layer network of bipolar activation function (hyperbolic tangent). The input vector were the data for the location of the public buildings in space (coordinates $x$ and $y$ of the centre of gravity of the object), the surface of the building and the technology of the implementation (coded numerical form). The output vector ware the values of potential savings arising from the improvement of the buildings to the standards specified in table 5, estimated on the basis of energy audits carried out in the area of Zielona Góra. Training set consisted of $65 \%$ of the data in particular quarters, and test set consisted of $35 \%$ of the data. Due to the limited number of data, a validation set that could be used in the process of the ongoing training, was not created. Graphic illustration of approximated obtained using a network of potential savings is featured on the figures contained in table 5 . 


\section{Results and discussion}

Research results presented in the work made it possible to identify potential in savings and the differences arising from the plot ratio of development with public buildings in various parts of the city of Zielona Góra. This knowledge allows us to adapt the policy of the city development to optimize the benefits of improving public buildings to standards ( 95 and $70 \mathrm{kWh} /(\mathrm{m} 2 /$ year)) set in the technical conditions and legislative documents. Energy requirements of cities are complex and multifaceted. As a consequence of the State policy adopted, cities should improve the current system of power supply and energy consumption and implement new solutions in a coordinated manner, thus optimizing synergies between all the possible energy savings solutions. Growing demand for electricity and heat and an increase in its prices, as well as the use of renewable sources, is an important energy challenge, which would be better dealt with in its complexity and not separately as it is often the case [4].

Table 5. Numerical characteristics of analysis performed.

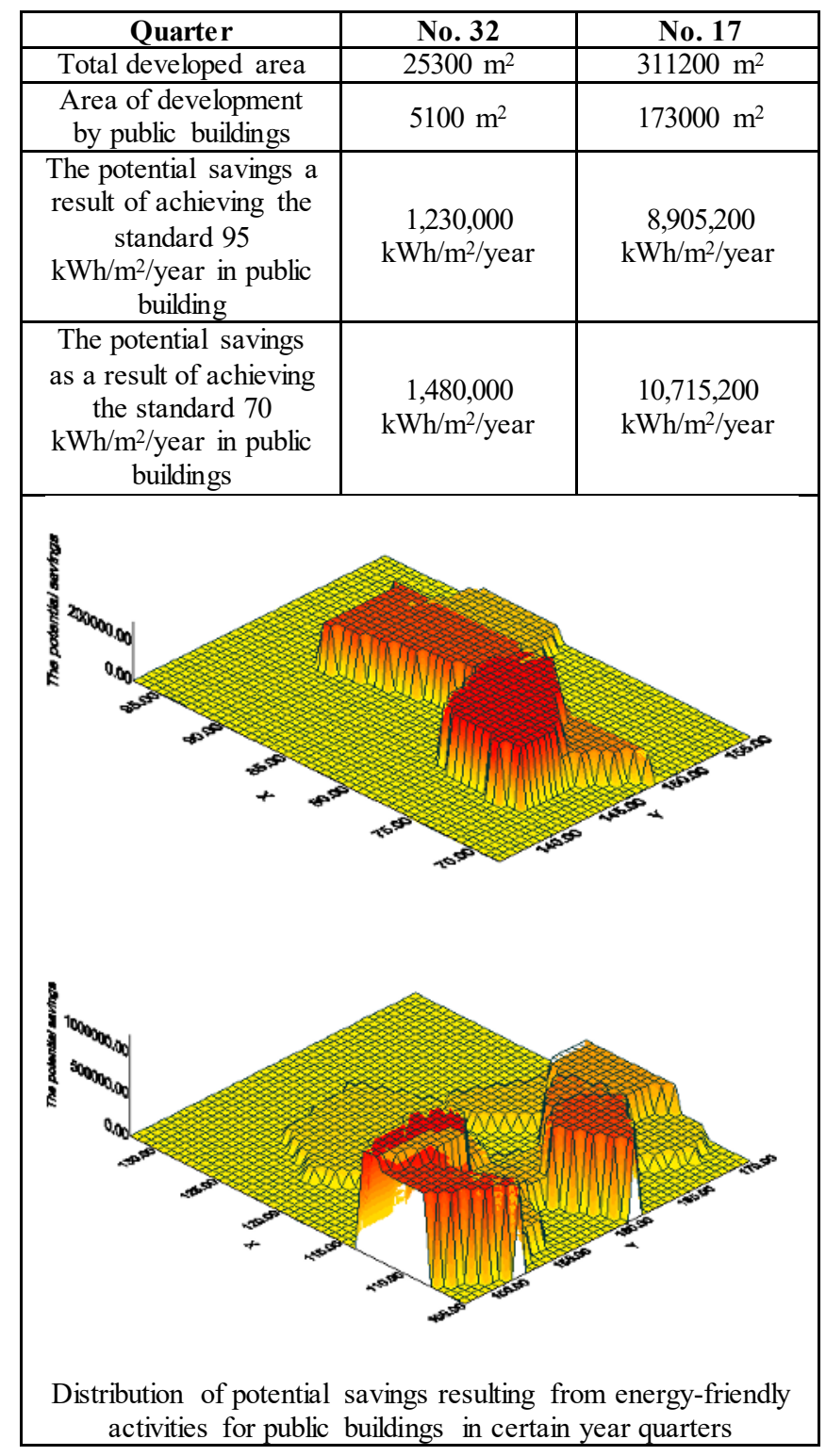

Fabrri and Tronchin (2015) described another challenge for the construction real estate industries, which is formed as a question: is there a link between the buildings with low and high demand for energy and the quality of their use? Quality, which, in case of buildings which are representative for municipal authorities and the city should not be dependent on the standards defining the height of rooms, transposition and technical solutions. EN 15251 standard specifies the internal input parameters for the design environment and assess the energy performance of buildings for indoor air quality, thermal comfort, lighting and acoustics [26].

The use of renewable energy sources is increasing especially in Mediterranean climate, it works as a strategy to reduce energy consumption in buildings. The reduction of the energy demand of the building is based on the use of construction elements, which are able to absorb passively, distract or collect energy [27].

In 2011 and 2012, in four cities: Shanghai, Tianjin, Shenzhen, Chongqing - a pilot programme of increasing energy efficiency in modernized commercial buildings was implemented [28]. On the basis of the actual research and expert interviews, a comparative analysis of motivation used in local politics was conducted. The results indicated that, in order to maximize efficiency and reduce energy consumption changes in administrative policy and support should be applied in the form of fiscal subsidies to existing commercial and public buildings, such as schools. Taking into account local economic conditions and fiscal capacity, the actual energy savings and a policy of incentives in order to modernize the economy was proposed. It is specified in the technical solutions that power management by: optimization of working time, changes in human behavior, lighting system and modernization of an air conditioning system can be done without a subsidy [28].

\section{Summary}

Public buildings in every city are the municipalities representative buildings, courts, swimming pools, schools, libraries, museums, and more. They often decide on the reception and perception of the city. Buildings of important social role. In the urban tissue, they make up one third of the volume. City policy should support changes to increase the energy efficiency of these buildings. Currently established technical criteria (energy characteristics) do not comply with the existing buildings. Newly built investment will fail to reach the criteria without the use of devices based on obtaining energy from RES. Energy policy of a city should be more diverse. It would be advisable to run programs to promote energy-efficient construction, so as to recommend potential investors beneficial solutions along with a possibility of financial support.

Artificial neural networks allow to obtain beneficial results in practical applications such as: approximation, interpolation, recognition and classification of patterns, compression and many more. It is worth noticing that modelling potential savings which result from the improved energy efficiency, can be successfully applied with artificial neural networks, which due to their nonlinear nature represent an advanced modelling technique 
capable of mapping complex relations. In this article, the use of neural networks, which as input vector used the coordinates $(x, y)$ of the centre of gravity, the area of a public building and its building technology, has allowed modelling of the deployment of energy savings potential on two quarters of the city of Zielona Góra. At the same time, it is worth indicating that the used approach will be available in the future to model the deployment of potential savings for the whole city.
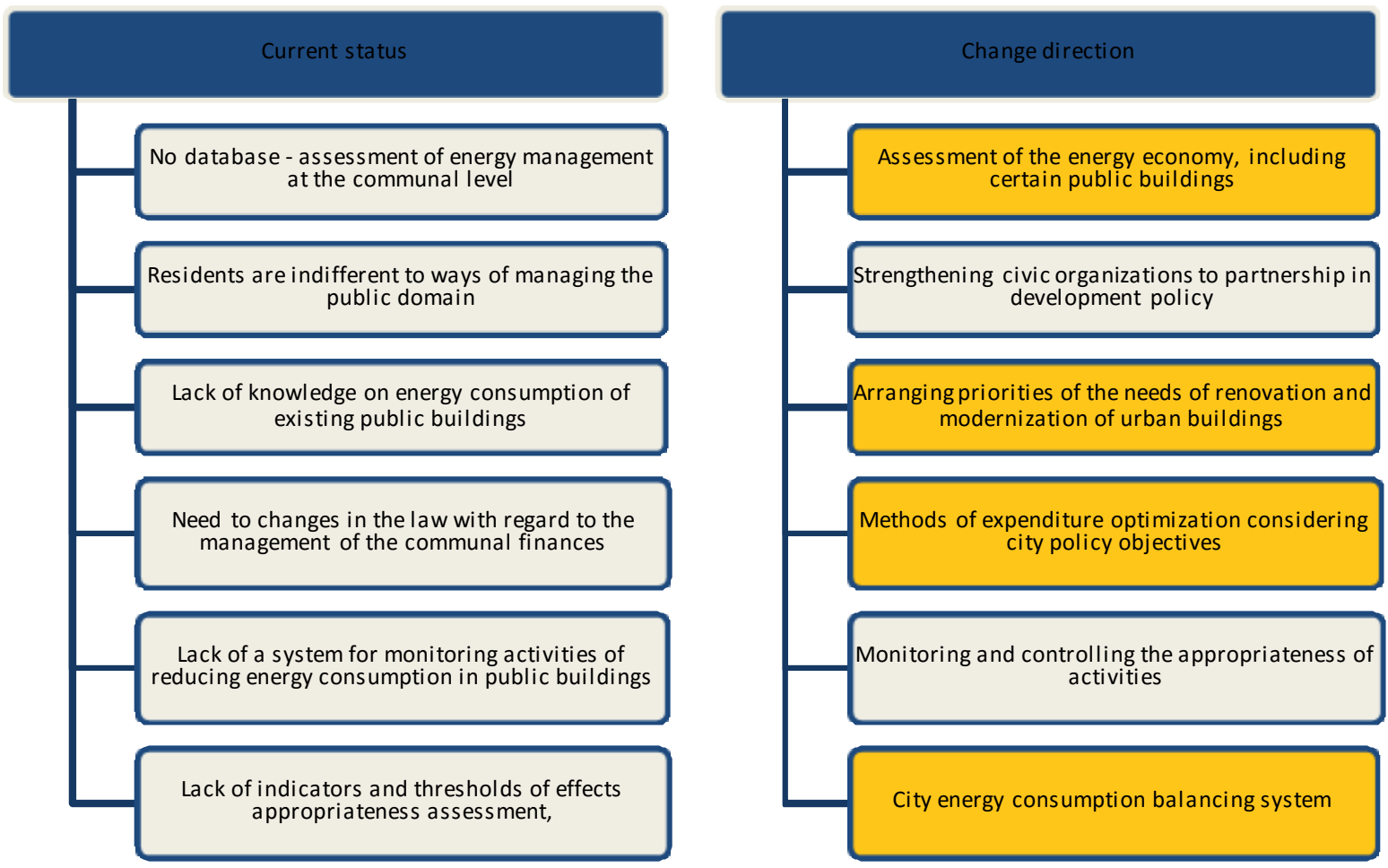

Figure 3. The possible practical actions supporting city management for increasing energy efficiency in public buildings. Own studies

\section{References}

1. M. Saffari, A. de Gracia, S. Ushak, L. Cabeza, Energ Buildings 112, 159-172 (2016)

2. K. Fabbri, Energy 89, 244-258 (2015)

3. M. Santamouris, Sol Energy 128, 61-94 (2016)

4. C. Calvillo, A. Sánchez-Miralles, J. Villar, Renew Sust Energ Rev 55, 273-287 (2016)

5. A. Stefanović, M. Bojić, D. Grodić, Energ Buildings 76, 57-63 (2014)

6. D. Teodorescu, A. Vartires,Energ Procedia 85, 530538 (2016)

7. A. Tummala, R. Velamoti, D. Sinha, V. Indraja, V. Krishna, Renew Sust Energ Rev 56, 1351 -1371 (2016)

8. F. Scarpa, L. Tagliafico, Appl Therm Eng 100, 820828 (2016)

9. A. Chmielewski, R. Gumiński, J. Mączak, S. Radkowski, P. Szulim, Renew Sust Energ Rev 60, 930-952 (2016)

10. A. Bazan-Krzywoszańska, M. Mrówczyńska, A. Łączak, M. Skiba, Energ Buildings 118, 170-180 (2016)

11. L. Bettencourt, J. Lobo, D. Helbing, C. Kuhnert, G. West, P Nat Acad Sci of the USA 104 (17), 73017306, (2007)

12. Directive $2009 / 29 /$ EC of the European Parliament and of the Council of 23 April 2009 amending Directive 2003/87/EC so as to improve and extend the greenhouse gas emission allowance trading scheme of the Community

13. Directive 2010/31/EU of the European Parliament and of the Council of 19 May 2010 on the energy performance of buildings

14. Directive 2012/27/EU of The European Parliament And Of The Council of 25 October 2012 on energy efficiency, amending Directives 2009/125/EC and 2010/30/EU and repealing Directives 2004/8/EC and $2006 / 32 / \mathrm{EC}$

15. Ministerstwo Gospodarki, Krajowy Plan Działań dotyczacy efektywności energetycznej dla Polski 2014, Warszawa (2014)

16. Ministerstwo Infrastruktury i Rozwoju, Wspieranie Inwestycji w Modernizację Budynków, Warszawa (2014)

17. Ustawa z dnia 15 kwietnia 2011 r. o efektywności energetycznej (Dz. U. z 2015r. poz. 2167 t.j. z późn. $\mathrm{zm}$.)

18. Ustawa $\mathrm{z}$ dnia 10 kwietnia 1997 r. Prawo energetyczne (Dz.U. z 2012r. poz. 1059 t.j. z póżn. $\mathrm{zm}$.)

19. Ustawa z dnia 27 marca 2003 r. o planowaniu i zagospodarowaniu przestrzennym (Dz.U. z 2015 poz. 199 z późn. zm.)

20. Energetyczny Audyt Miejski dla miasta Zielona Góra, Zadanie badawcze nr 1: Analysis of the possibilities and socio-economic impact of raise in energy efficiency in the construction industry. 
Umowa Nr SP/B/1/91454/10, NCBiR, Zielona Góra (2011)

21. Program Operacyjny Infrastruktura i Środowisko 2014-2020, Ministerstwo Infrastruktury i Rozwoju, Warszawa (2015)

22. Obwieszczenie Ministra Infrastruktury z dnia 17 lipca 2015r.w sprawie ogłoszeniajednolitego tekstu rozporządzenia Ministra Infrastruktury w sprawie warunków technicznych, jakim powinny odpowiadać budynki $i$ ich usytuowanie (Dz. U. z 2015 r. poz. 1422)

23. Ustawa z 21 listopada 2008 r. o wspieraniu termomodernizacji i remontów(Dz. U. z 2014 r.poz. 712)

24. Ch. M. Bishop, Pattern Recognition and Machine Learning, Springer, New York (2006)
25. M. Mrówczyńska, Studium nad doborem metod inteligencji numerycznej do rozwiazywania problemów z geodezji inżynieryjnej, Oficyna Wydawnicza Uniwersytetu Zielonogórskiego, Zielona Góra (2015)

26. K. Fabbri, L. Tronchin, Energ Procedia 78, 27782783 (2015)

27. J. Tenorio, J. Sánchez-Ramos, A. Ruiz-Pardo, S. Álvarez, L. Cabeza, Energy 8, 8630-8649 (2015)

28. J. Hou, Y. Liu, Y. Wu, N. Zhou, W. Feng, Energ Policy 88, 204-215 (2016)

29. http://www.nbp.pl/transfer.aspx [date of access: 23.07.2016]

30. http/stat.gov.pl [date of access: 23.07.2016]

31. License no DR-G.6642.1059.2016.AW_0862_P of 14.03.20E16 